\title{
SELF-DIRECTED LEARNING IN THE CONTEXT OF A NURSING CURRICULUM: DEVELOPMENT OF A LEARNING PLAN
}

\section{B Majumdar}

\begin{abstract}
The rapid pace at which biological health breakthroughs and advancements in technology occur is creating unique challenges to health care programmes. The curricula of all health care programmes will need to be set in learning environments where students will be able to develop learning skills that are transportable across situations, over a whole lifetime. This article attempts to focus on self-directed learning (SDL) concepts and the development of a learning contract/plan, including the roles of both the student and faculty in self-learning approaches and contractual development.
\end{abstract}

\section{INTRODUCTION}

By redefining the relationship between the teacher and student, and placing more control in the hands of the student, self-directed learning approaches aim to be more effective than traditional learning methods. In simple terms self-directed learning is a set of "activities where primary responsibility for planning, carrying out, and evaluating a learning endeavour is assumed by the individual learner (Brockett, 1983, p. 16)." It is a style of leaming that draws upon the experiences and focuses upon the needs of the leamer to a far greater extent than traditional teacher driven learning methods (Knowles, 1975). It aims to develop certain "action oriented skills" (Herman, 1980) like setting goals, choosing learning methods, finding information and resources, and assessing programmes.

By allowing for individual learning styles, self-pacing and placing an emphasis on finding out what needs to be leamed for oneself, it is believed that the self-directed learning activity will impact on the student to a far greater extent than traditional methods of learning (D'A Slevin \& Lavery, 1991; Donald, 1976; Herman, 1980; Weinberg \& Stone-Griffith, 1992). Many authors assert that the self-directed leaming activity is able to provide higher degrees of confidence, self-assertiveness, and motivation for students (D'A Slevin \& Lavery, 1991; Wickenden.
1989; Wilson, 1993) and evidence is beginning to appear that may corroborate these strong assertions. (Wickenden, 1989; Wilson, 1993).

\section{LITERATURE REVIEW}

Wilson (1993) conducted a study $(n=117)$ comparing the impact of traditional lecture based learning against the effects of self-directed learning on the academic performance, attitudes, anxiety levels, and the acquisition of basic nursing techniques, on 2nd year baccalaureate nurses. Pretest-postest was used to measure academic performance, Spielberger's State-Trait Anxiety Inventory to determine test anxiety, Kolb's Learning Style Inventory to identify each participants' preferred learning style, and the Kelly adjective Rating Scale to assess students' attitudes toward each teaching strategy. The study revealed that the self-directed group scored significantly higher on academic performance, had significantly less anxiety before the final exam, and a significant number felt the learning strategy had more interest and practical value and less dullness than the traditional learning method (Wilson, 1993).

Another study of nursing education in a clinical setting found similar results (Wickenden, 1989). The nursing students who participated in the case study using a self-directed learning activity were monitored from the three perspectives of: 1) the student and nurses, 2) permanent qualified staff on the wards, and 3) nurse teachers.

The study revealed that there was increased motivation to learn, improved study habits, more questioning by the nursing students, and the quality of teaching improved. It was felt that the total effect of using the self-directed learning method was one of an enhanced teaching learning environment within the clinical setting (Wickenden, 1989).

Even though there may be no compulsory lectures to attend and no assignments given solely at the discretion of the teacher, this is not a totally unstructured approach to learning The learning plan and the interactions with the faculty member provide the boundaries, which are negotiated between the student and faculty member, to the learning activity. The requirements of the institution and the course in terms of expected levels of competency and knowledge (as reflected in the learning plan) help to provide structure to the self directed learning experience.

\section{LEARNING PRINCIPLES}

Guilhert (as cited by Majumdar, 1987) states that learning in general possesses the following characteristics. It is primarily controlled by the learner, unique and individual, affected by the total state of the leamer, co-operative and collaborative and an evolutionary process. Learning for adults is characterized by the following five principles: Adults need to recognize the purpose of learning,

- adults will build on their own life experiences.

- adults will learn best if the learning is task, problem, or inquiry centred,

- adults will learn when they are ready, and

- adults are motivated to leam by growth, accomplishment, curiosity and self-esteem (Weinberg \& Stone-Griffith 1992). Both of these sets of principles are very similar to the assumptions on which self-directed learning is based.

Knowles $(1975,1984)$ bases his development of a self-directed learning method on principles that he sees as alternatives to traditional pedagogic methods of teaching and learning. He assumes the following:

- that adult learners need to know the importance of learning something before they will undertake to leam it,

- the self-concept of the learner includes being personally responsible for their own decisions and being treated as being capable of self-direction,

- the learners' experience is important to their leaming and self-identity,

- the leaming is something that will help perform certain tasks, or deal with certain situations,

- adults are ready to leam only when they have decided they need to leam, and 
- adults are more responsive to internal motivators like self-esteem or quality of life.

Knowles (1986) also asserts that each adult learner has an unique style and pace of learning, unique outside commitments and pressures, and unique goals and motivations. When these assumptions are considered in conjunction with the belief that adult learning is an internal process facilitated by outside helpers it follows that the learning strategies must be unique and highly individualized (Knowles, 1986). These principles accord very closely to the principles of adult learning and reflect the natural capacities and tendencies of adults when learning is undertaken.

\section{CONTRACT DEVELOPMENT}

Integral to the self-directed learning method is the development of a learning contract or learning plan. As Sutcliffe (1991) notes in her work with nurses continuing their education using self-directed learning methods, a learning contract can be essential to the success of such endeavour. A learning contract is an agreement between the student and faculty member which outlines in detail the exact course requirements and the expectations of the student and faculty member.

The learning plan is comprised of five components ie the course expected clinical behaviours, student learning objectives, resources to be used, evidences and the terms of evaluation (Donald, 1976; Knowles, 1975). While informing the student of the course expected clinical behaviours, the faculty member should also convey the knowledge which the students must acquire, the learning experiences that are necessary and where proficiency must be attained. The student learning objectives will allow a student to determine what $\mathrm{s} / \mathrm{he}$ must leam given the skills and knowledge s/he already possesses. By outlining personal learning objectives, the student will provide an opportunity for the faculty member to assist her in making sure that goals are reconciled with the requirements of the institution and the course (Knowles, undated). The faculty member can also help the student determine if the personal objectives are reasonable and attainable.

The next component of the learning plan is the identification of resources. Stewart and Shank (as cited by Donald, 1976) suggest that many different types of information media should be utilized in order to maximize the student's learning capabilities. Faculty members and personnel who will be valuable resources to the student can be identified at this stage also (Majumdar, 1992).

The student and faculty member will now come to an agreement as to what learning evidences will be undertaken by the student in order to fulfil the specific learning objective (Donald, 1976). This includes the drafting of a timetable to indicate when certain learning experiences will be undertaken, and when presentations or reports will be submitted.

The final (and perhaps the most crucial) part of the learning contract is the style of evaluation. At this point it must be made clear how, and by whom, the student's achievements will be evaluated. The student will develop specific criteria that the faculty member will follow to evaluate whether or not the learning objectives and the clinical expected behaviours have been achieved. Both the student and faculty member must be involved in negotiating the terms of the learning contract with the final result being, "satisfactory or [unsatisfactory] completion of the learning activities which manifest achievement of the stated objectives" (Donald, 1976, p.5).

In order to develop the learning plan it has been suggested that the following steps of scientific inquiry be followed (Knowles, 1975):

- What question needs to be answered?

- What information is needed to answer that question?

- What are the best available sources for obtaining this information?

- What is the most efficient manner of obtaining data from these sources?

- How will the information be organized and presented?

- How will the validity of the results be tested?

\section{APPLICATION OF SDL CONCEPTS WITHIN THE CONTEXT OF A NURSING CURRICULUM:}

Following this process of development, the final product will closely resemble the learning plan given in Figure 1. In the Faculty of Nursing at McMaster University, Canada, the student is required to develop a leaming plan for each clinical placement. Development of the leaming plan usually occurs between two and three weeks after the clinical placement has begun. By becoming oriented with the setting during the initial two to three weeks the student will be able to determine what experiences s/he wants to derive from the placement.

The learning objectives are to be representative of the course expected clinical behaviours which comprise the following six areas and must be reflected in the students' learning objectives:

1) problem-solving 2) knowledge 3) skill (practical) 4) interpersonal skill 5) self-directed learning and self-evaluation. The students' learning objectives based on these six criteria must be specific, feasible and measurable.

The student is expected to be creative in her choice of learning material, focusing on both written and human resources as for example, the use of nursing theory to compliment the practical experience or drawing upon hospital in-services, nurse educators, clinical nurse specialists, etc. The evidences the student chooses must be creative and feasible, fitting easily within the negotiated time frame. The final part of the learning plan, the terms of evaluation, will offer a highly specific and extensive outline of how the tutor/preceptor will evaluate the students' evidence of her objectives.

If difficulties should arise for the student during the term the learning plan can be renegotiated but the student must take full responsibility for the objectives that she has decided upon. If the student feels that the objectives are not feasible, faculty must be approached. All dates that were agreed upon for providing evidences, if not renegotiated, must be honoured. It is crucial that the student take the development of a learning plan seriously for very often the acquisition of nursing skills and competencies in a clinical setting are dependant on the establishment of a comprehensive and well-structured learning plan.

\section{FACULTY INVOLVEMENT}

It is essential for faculty members to interact closely with students. In the initial steps of building a learning plan the faculty member must be a facilitator guiding rather than directing the student (Barrows, 1971). This will result in a relationship in which "the student decides and the teacher responds." (D'A Slevin \& Lavery, 1991) This behaviour is manifested in the building of the learning plan. In the initial stages the faculty member is needed to communicate to the student the specific expected clinical behaviours of the course and then aid the student in reconciling her learning objectives with the course expected clinical behaviours.

The faculty member is needed to aid in the development of a timetable and the terms of the final evaluation. Throughout this process any decisions reached between the faculty member and the student will be the result of negotiation (Iwasin, as cited in D'A Slevin \& Lavery, 1991). In order for this process to be successful the interactions between faculty member and student need to be an exchange between equals, where control is shared equally (Herman, 1980).

After the learning contract is completed and before the final evaluation, the faculty member remains an integral part of the students' learning experience. D'A Slevin and Lavery (1991) assert that all students need continuous support from their teachers and have a right to expect it. If supervision is not present, working alone in a teacherless 
LEARNING PLAN

\begin{tabular}{|c|c|c|c|}
\hline $\begin{array}{l}\text { Learning } \\
\text { Objectives }\end{array}$ & $\begin{array}{c}\text { Learning Resources } \\
\text { and Strategies }\end{array}$ & Evidences & $\begin{array}{l}\text { Criteria for } \\
\text { Evaluation }\end{array}$ \\
\hline $\begin{array}{l}\text { What do I want or need } \\
\text { to learn? } \\
\text {-knowledge } \\
\text {-skills } \\
\text {-attitudes/values }\end{array}$ & $\begin{array}{l}\text { What or who can help } \\
\text { me learn what I want to } \\
\text { learn? } \\
\text { What will I do to meet } \\
\text { my objectives? }\end{array}$ & $\begin{array}{l}\text { How will I demonstrate } \\
\text { what I have learned? } \\
\text { What deadline? }\end{array}$ & $\begin{array}{l}\text { Who will evaluate my } \\
\text { evidence? } \\
\text { Based on what criteria? }\end{array}$ \\
\hline $\begin{array}{l}\text { Objective \#1: } \\
\text { - To gain the } \\
\text { appropriate } \\
\text { knowledge and skills to } \\
\text { conduct effective and } \\
\text { comprehensive } \\
\text { interviews with clients } \\
\text { in a psychiatric } \\
\text { setting } \\
\text { - Peplau's Model of } \\
\text { Nursing will be applied } \\
\text { to objective \#1 in } \\
\text { order to facilitate } \\
\text { application of } \\
\text { appropriate } \\
\text { communication } \\
\text { techniques during } \\
\text { interviews with } \\
\text { clients }\end{array}$ & $\begin{array}{l}\text { 1) Observation of } \\
\text { interviewing } \\
\text { techniques by } \\
\text { nursing staff } \\
\text { 2) role playing with peers } \\
\text { in post-conference } \\
\text { 3) Sheriff \& Garner (Jan, } \\
\text { 1993).Interviewing } \\
\text { skills package. } \\
\text { 4) Foster (March, } \\
\text { 1982).Rules of thumb: } \\
\text { Hints for the } \\
\text { psychiatric nursing } \\
\text { student. } \\
\text { 5) Peplau's Interpersonal } \\
\text { relations in nursing. }\end{array}$ & $\begin{array}{l}\text { 1)Interview: } \\
\text { - interview skills } \\
\text { package will be used } \\
\text { - hand in evaluation form } \\
\text { to tutor and preceptor } \\
\text { - verbally discuss results } \\
\text { with tutor/preceptor } \\
\text { following interview } \\
\text { Due: Feb } 12 / 95 \\
\text { 2)Present Peplau's } \\
\text { theory to peers in } \\
\text { post-conference } \\
\text { Due: Mar } 7 / 95\end{array}$ & $\begin{array}{l}\text { 1)tutor/preceptor will be } \\
\text { given checklist or } \\
\text { evaluation form of } \\
\text { topics to be covered } \\
\text { during interview with } \\
\text { one client } \\
\text {-checklist will be } \\
\text { reviewed with tutor/ } \\
\text { preceptor a week prior } \\
\text { to interview in order to } \\
\text { receive any necessary } \\
\text { suggestions } \\
\text {-verbal analysis of } \\
\text { completed interview by } \\
\text { student and } \\
\text { preceptor/tutor, based } \\
\text { on evaluation form } \\
\text { 2)Presentation to peers } \\
\text { will focus on the } \\
\text { application of Peplau's } \\
\text { Model to interview } \\
\text { process }\end{array}$ \\
\hline
\end{tabular}

Figure 1: Sample of a Learning Plan developed by a Level III BScN student in psychiatric placement

Source: McMaster University BScN Programme (1993). Leaming PLan Form. Hamilton ON

environment can be a frightening experience which may result in student indecision.

D'A Slevin and Lavery (1991) suggest that the faculty member acting in the supervisory role institute a series of frequently scheduled meetings with students to allow for a high degree of contact. This gives the student the opportunity to present work in an ongoing manner and to present any difficulties. The meetings also afford the faculty member an opportunity to present critiques of the students' work and provide adequate feedback. The faculty member should strive to establish an one to one relationship with the individual students. An important element of this relationship between student and faculty member is the level of trust that exists between them.

Drawing upon Knowles' learning contract approach to self-directed learning, Barnard (as cited by Herman, 1980) emphasizes that the interdependence of the instructor and the student is built on trust. Trust is an essential part of the self-directed learning activity in two ways - 1) trust must be present through the shared belief in the integrity of the learning contract, and 2) trust must also exist between the student and faculty member as individual persons. This is important to the learning activity as it allows for the faculty member and student to deal with problems that arise between them, "openly, directly and honestly." (Barnard as cited by Herman, 1980 , p.17).

The faculty member requires special training to be proficient in providing supervision and direction to the students (Barrows, 1971). Students need initial direction in the writing of their own objectives (Sutcliffe, 1991) and then in fulfilling the terms of the learning contract. In order to ensure that the faculty member can function in this capacity peer group meetings may be necessary (D'A Slevin \& Lavery, 1991). Peer groups allow faculty members to share their experiences and to receive any necessary instruction (D'A Slevin \& Lavery, 1991).

\section{EVALUATION}

A learning contract/plan aids the self-directed leaming process by providing an opportunity for the student to blend the requirements of the course with her own learning needs and styles (Knowles, 1975). The development of a contract allows for the student to tailor the pace of the leaming to her needs (Weinberg \& Stone-Griffith, 1992). It is also believed that student motivation is enhanced and sustained throughout the course, the relationship between student and faculty member is strengthened through the personal agreement of the contract, and the negotiation of the specifics of the learning creates a positive, reward oriented atmosphere where full development of the student is possible (Donald, 1976). In a study $(n=59)$ conducted by Soloman it was found that the development and use of learning contracts was beneficial. A questionnaire was developed which was distributed to the student supervisors of a clinical course in a physiotherapy programme and it was reported that ninety-five percent of 
the supervisors found the learning contract to be a useful tool. The responses in the questionnaires suggest that the use of a learning contract promotes negotiation between student and teacher, provides a flexible leaming environment, and promotes the acquisition of self-directed learning skills (Soloman, 1992).

Good communication between all persons involved is essential because within a self-directed learning activity there may be a tendency for interactions between students and faculty to occur less often than is optimal (Donald, 1976). Peterson and Dyck (1986) conducted a study of a nursing programme using systems theory in order to isolate subsystems within the programme and the interactions between the subsystems. This study is pertinent as it highlights the need for effective communication between all those concerned, which within the context of the learning plan applies directly to the interactions between student and faculty member. Peterson and Dyck (1986) concluded from examining the interactions between students, instructors, and clinical resource persons, that "open and frequent communication" between all these groups was essential. This frequent communication between all the groups included information passing from instructors to students and the implementation of feedback opportunities between all three groups. Peterson and Dyck (1986) felt that if problems arose they were dealt with more effectively when there was good communication between all parties already established.

Acknowledgement: The author would like to thank Grant MacMahon, B.A., for his contribution to this paper.

\section{REFERENCES}

Barrows, H.S. (1971). Simulated Patients. Springfield, Ill: Charles C. Thomas.

Brockett, R. (1983). Self-directed learning and the hard to each adult. Lifelong Learning: The Adult Years, 6(8), 16-18.

Donald, J.G. (1976). Contract for learning Learning and Development, 7(5).

Herman, R. (1980). The design of self-directed leaming. Toronto: OISE, $1-43$ and 53 .

Knowles, M. (1975). Self-directed learning: A guide for learners and teachers. New York: Association Press.

Knowles, M. (1984). The adult learner: A neglected species (3rd ed.). Houston: Gulf Publishing Co.

Knowles, M. (1986). Using learning contracts: Practical approach to individualizing and structuring learning. San Francisco: Jossey-Bass Publishers.

Majumdar, B. (1987). A self-directed instructional manual for health professionals. Masters Thesis. 1987

Majumdar, B. (1992). Self-directed learning: The development of a learning plan. The Nursing Journal of India, LXXXIII, (4), 93-96.

McMaster University BScN Programme (1993). Learning Plan Form. amilton. ON.

Peterson, J.M., \& Dyck, S. (1986). Systems theory facilitates student practice in self-directed learning courses. Nurse Educator, 11(5),12-15

Solomon, P. (1992). Learning contracts in clinical education: Evaluation by clinical supervisors. Medical Teacher, 14(213), 205-10

Sutcliffe, L. (1991): Freedom to learn. Nursing Times, 87(35), 43-44.

Weinberg, L., \& Stone-Griffith, S. (1992). Altemate methods of eaching: Use of self-learning packets. Joumal of Post Anethesia Nursing, 7(6), 392-397.

Wickenden, A.S. (1989). Self-directed learning in nurse education: A case study on an orthapaedic ward. Doctoral Abstracts International, p. 3112.

Wilson, B.K. (1993). Comparison of two teaching strategies for teaching basic nursing skills to baccalaureate nursing students. Doctoral Abstracts International, 2233.

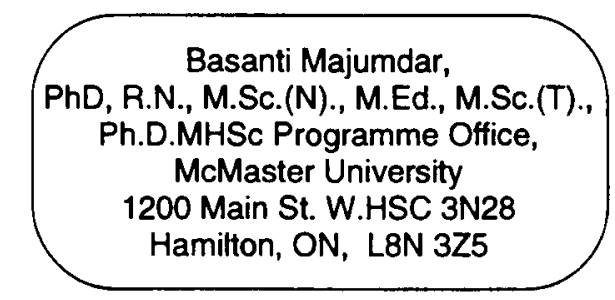

